\title{
SEKSISME DAN KEKERASAN SEKSUAL DI FLORES
}

\author{
Helenerius Ajo Leda \\ Gmail: henajo66@gmail.com \\ Staf Pengajar Ilmu Pemerintahan STPM Santa Ursula Ende
}

\begin{abstract}
Abstraksi
Artikel opini ini mengulas tentang fenomena kejahatan seksual yang menimpa perempuan dan anak-anak yang marak terjadi di Flores. Berdasarkan data yang dihimpun Truk Maumere sekitar 69,24\% kekerasan seksual masif terjadi di ranah personal dan komunitas yang menyasar anakanak remaja sebanyak 16 korban dan pelakukanya adalah orang-orang dekat dari korban. Dengan menggunakan pendekatan ekonomi-politik, tulisan ini berargumen bahwa persoalan kejahatan seksual dalam bentuk apapun tidak terlepas dari struktur tatanan masyarakat berkelas (feodalisme dan patriarki) yang melanggengkan seksisme. Oleh karena itu, dengan menempatkan seksisme dan praktek kejahatan seksual sebagai persoalan sistemik dan struktural maka implikasinya adalah dengan membangun gerakan sosial politik, yang melibatkan seluruh seluruh komponen untuk melawan praktek kejahatan seksual yang terus berlangsung hingga saat ini.
\end{abstract}

\section{Katakunci: seksisme, kekerasan seksual, feodalisme, patriarki, flores}

\section{Pendahuluan}

Fenomena kejahatan seksual terhadap perempuan dan anak terus aktual dari waktu ke waktu. Laporan demi laporan seputar kejahatan seksual terus mengalir tiada habisnya, dan kita senantiasa dipertontonkan oleh aksi jahanam ini yang tampil dalam ruang-ruang vitrual. Fenomena ini menjadi tren yang kian meningkat dan bahkan terus menguat dalam tatanan masyarakat kita.

Berbagai media massa baik cetak maupun elektronik kian up to date melaporkan aksi kejahatan seksual. Pada penghujung Januari
2020, harian umum Flores Pos (FP) dan media online Voxntt.com memberitakan kasus kekerasan seksual yang menimpa seorang remaja putri berinisial MKG. Penyintas mengalami tindakan kekerasan sesual oleh YN, di Rewokoli, Kelurahan Dangan Kecamatan Aesesa, Nagekeo.

Praktek kejahatan seksual yang terjadi di Nagekeo hanyalah contoh dari sekian banyak kasus yang terjadi di bumi Flobamora umumnya dan NTT khususnya. Di beberapa kabupaten lainnya seperti di Sikka-Maumere, berdasarkan cacatan akhir tahun Truk Maumere sekitar 69,24\% 
kekerasan seksual masif terjadi di ranah personal dan komunitas yang menyasar anak-anak remaja sebanyak 16 korban Pelakukanya adalah orang-orang dekat dari korban (florespos, 1 Februari 2020).

Di Lembata, berdasarkan pemberitaan Poskupang bahwa tercatat ada sejumlah 177 kasus kehamilan yang menimpa anak di bawah umur, dan diperkirakan jumlahnya akan bertambah seiring bertambahnya kasus kekerasan terhadap anak dibawah usia 20 tahun (poskupang, 29 Januari 2020).

Data-data kejahatan seksual yang disajikan diatas ibarat pucak gunung es, masih banyak kasus serupa yang menimpa perempuan dan anak-anak kita terjadi di tempat-tempat lain yang tak sempat di eksplorasi dalam tulisan ini. Begitu pun, masih banyak juga penyintas yang belum berani speak up atas kasus yang menimpa mereka diluar sana.

Terkait dengan masalah ini, lantas pertanyaannya adalah mengapa kejahatan seksual terus terjadi dan kian menigkat dalam tatanan masyarakat kita? Latar belakang struktural macam apa yang mengkondisikan praktek kejahatan seksual tetap langgeng hingga saat ini? Bagaimana jalan keluar untuk menghancurkan kejahatan seksual ini?

\section{Seksisme dalam Sistem Sosial Feodalisme dan Patriarki}

Maraknya kasus kejahatan sekusal yang menimpa perempuan dan anak-anak merupakan buah dari seksisme. Kamus Merriam Webster mendefinisikan seksisme sebagai prasangka atau diskriminasi berdasarkan jenis kelamain, yang hadir dalam bentuk kekerasan dan kejahatan seksual.

Secara eksplisit, Mansour Fakih dalam bukunya Analisis Gender dan Transformasi Sosial menyebutkan delapan bentuk kejahatan yang dikategorikan sebagai kekerasan seksual, diantaranya; pemerkosaan, pemukulan dan serangan fisik, penyiksaan, kekerasan dalam bentuk pelacuran, pornografi, kekerasan terselubung (memegarng/menyentuh bagian tertentu dari tubuh), pelecehan seksual secara verbal, misalnya menyampaikan lelucon jorok secara vulgar pada seseorang dengancara yang ofensif, menyakiti atau membuat malu sesorang dengan omongan kotor, meninterogasi seseorang tentang kehidupan atau kegiatan seksual, meminta imbalan seksual dalam rangka janji untuk mendapatkan sesuatu dan lainnya.

Karena seksisme merupakan diskriminasi berdasarkan jenis kelami, maka seksisime menarget bukan hanya kaum perempuan namun juga laki-laki dari kelas yang lemah, walalupun fakta memperlihatkan kaum perempuan dan anak-anak seringkali menjadi korban dari praktek predatoris ini.

Begitupun para pelaku bukan hanya laki-laki saja (male sexism), kaum perempuan juga dapat menjadi aktor (female sexism) kejahatan ini. Pada intinya, persoalan seksisme terletak pada ketimpangan relasi kekuasaan antara satu kelompok/kelas terhadap kelompok/kelas lain, tanpa memandang perbedaan gender.

Dalam konteks sosial kultural masyarakat flores, seksisme langgeng berkat perkawinan 
antara dua entitas budaya feodalisme dan patriarki. Feodalisme diartikan sebagai sebentuk kekuasan dalam tatanan masayrakat yang dijalankan oleh kelas-kelas bangsawan/tuan tanah yang memegang monopoli atas faktor-faktor produksi.

Patriarki sebagai sistem sosial yang memprivilesekan para laki-laki dengan mengorbankan kaum perempuan. Dalam budaya patriarki, kaum laki-laki memegang kekuasaan utama dan mendominasi dalam peran-peran kepemimpinan politik, privilese sosial, menguasai properti dengan secara spesifik menyingkirkan sebagian besar perempuan.

Di Flores, feodalisme dan patriarki yang masih bercokol telah memberikan sumbasih bagi tumbuh suburnya praktek-praktek penindasan dan penyingkiran terhadap perempuan di segala sektor. Di Nagekeo misalnya, kepemilikan tanah (tana watu), rumah adat (sa'o waja/sa'o pu'u), hak atas harta warisan selalu dikuasai dan dikontrol oleh laki-laki (mosalaki). Dan disetiap upacara ritual adat (buku gua) kaum lakilaki lah yang lebih berperan.

Para tuan tanah (mosalaki feodal) di Flores, selain memiliki kuasa dan kontrol terhadap tanah dan budak sebagai faktor produksi, juga memiliki kontrol atas tubuh perempuan. Misalnya di Boawae-Nagekeo, sebagai simbol kekuasaan seorang bangsawan (mosalaki) lokal adalah harus memiliki istri (fai) dalam jumlah yang banyak.

Praktek budaya feodal dan patriarki yang saling dalam berpaut itu, membuat laki-laki lah berada pada kedudukan yang dominan/ordinat sedangkan perempuan subordinat. Kondisi semacam ini menyebabkan ketimpangan relasi kekuasaan di ranah personal maupun di ranah publik. Perempuan menjadi objek yang senantiasa di kontrol, dieksploitasi tenaga dan tubuhnya. Keadaan inilah membuat perempuan seringkali mengalami dikriminasi dan kekerasan dalam segala hal, termaksuk diskriminasi seksual.

Dalam budaya feodal-patriarki ketimpangan kekuasaan yang menyebabkan dikriminasi dan kekerasan terhadap perempuan, justru terus dilanggekan dan dilegitimasi oleh sistem sosial dan sistem nilai masyarakat. Misalnya, kejahatan seksual yang sulit diungkap dan ditangani kerena sering dikaitkan dengan konsep moralitas dan sistem nilai masayrakat.

Perempuan dianggap sebagai simbol kesucuan dan kehormatan, karenanya ia kemudian dipandang menjadi aib ketika mengalami kekerasan seksual. Seperti yang terjadi di Sikka-Maumere, para penyitas/korban kekerasan seksual di usir dari kampung halamannya oleh warga kampung dimana mereka tinggal. Pengusiran terhadap korban di sinyalir takut akan aib yang akan dialami oleh warga (Florespos, 31 Januari 2020). Korban/penyintas juga sering disalahkan sebagai penyebab terjadinya kekerasan seksual, inilah yang membuat korban seringkali bungkam.

Lantas bagaimana jalan keluar untuk menghancurkan seksime, termasuk kejahatan seksual? Tentu kita harus menempatkan seksisme dan praktek 
kejahatan seksual sebagai persoalan sistemik dan struktural yang diakibatkan oleh sistem feodalisme dan patriarki yang terus dilanggengkan hingga saat ini dalam organisasi-organisasi sosial kemasyarakat.

Maraknya kasus kekerasan seksual yang terus terjadi, bukan karena pelakunya berwak bejat, tidak bermoral, tidak beriman, tapi lebih desebabkan oleh struktur sosial kemasyarakatan kita yang terus memproduksi dan mereproduksi aktor-aktor seksis. Dengan demikian persoalan kejahan seksual dalam bentuk apapun tidak terlepas dari tatanan masyarakat yang melanggengkan seksisme. Seksisme telah menjadi sistem berpikir yang mengendap dalam berankas memori kolektif. Budaya feodal dan patriarki yang menyejarah dalam peradaban masyarakat kita menjadi sistem sosial yang mengatur sistem hidup bersama dari orang-orang atau kelompok orang yang didalamya.

\section{Penutup}

Dengan menempatkan seksisme dan praktek kejahatan seksual sebagai persoalan sistemik dan struktural maka implikasinya adalah dengan membangun gerakan sosial politik, yang melibatkan seluruh seluruh komponen.
Gerakan sosial politik diarahkan untuk membangun kesadaran kolektif publik, bahwa kasus kekerasan seksual yang terus terjadi menunjukan predikat kemanusian kian bangkrut ke titik nadir, telah terjadinya proses penghianatan terhadap eksistensi kemanusiaan. $* * *$

\section{Daftar Pustaka}

Fakih, Mansour. 2013. Analisis Gender dan

Transformasi Sosial. Yogyakarta:

Insist Pres

Florespos, 1 Februari 2020, "Pelaku Kekerasan Seksual di Sikka Didominasi Orang-orang Dekat".

Poskupang, 29 Januari 2020, "Lembata Darurat Kekerasan Anak".

https://voxntt.com > 2020/01/30 >Siswi SMP di Mbay Diduga Diperkosa Pamanya Sendiri | VoxNtt.com

https://www.merriamwbster.com/dictionary/sexism/ diakses, 12 Februari2020.

https://cylbauengo.blogspot.com/2015/pemb angunan-nagekeo-berbasis-budaya, diakses 12 Februari 2020 